\title{
Bone Marrow Fibroblasts from Children with Aplastic Anemia Exhibit Reduced Interleukin-6 Production in Response to Cytokines and Viral Challenge
}

\author{
DAGMAR DILLOO, RENATA VÖHRINGER, ANDREAS JOSTING, KERSTIN HABERSANG, \\ ANDREAS SCHEIDT, AND STEFAN BURDACH
}

Laboratory for Experimental Haematology and Bone Marrow Transplantation, Department of Pediatric Haematology/Oncology, Heinrich-Heine University Medical Center, 40225 Düsseldorf, Germany

\section{ABSTRACT}

Defects of the bone marrow microenvironment have been implicated in the pathogenesis of aplastic anemia (AA). We examined granulocyte/macrophage colony-stimulating factor (GM-CSF) and IL-6 production in bone marrow fibroblasts from five children with AA in response to cytokines and viral challenge with cytomegalovirus (CMV). Cytokine-stimulated IL-6 production in patients' fibroblasts was significantly reduced, whereas GM-CSF production was found to be comparable to normal controls. Also, CMV-mediated stimulation of IL-6 production was significantly lower in bone marrow fibroblasts from patients with AA. During the late phase of CMV-infection, IL-6 production was suppressed in CMV-infected fibroblasts from patients with AA with $90 \%$ inhibition of IL- 6 protein production and marked reduction in IL-6 mRNA accumulation. Defective IL-6 production in bone marrow fibroblasts might contribute to hematopoietic suppression in some patients with AA. (Pediatr Res 38: 716-721, 1995)

AA, aplastic anemia
NC, normal controls
GM-CSF, granulocyte/macrophage-stimulating factor
TNF- $\alpha$, tumor necrosis factor- $\alpha$
CMV, cytomegalovirus
CPE, cytopathic effect
MNC, mononuclear cells

AA is characterized by hypocellularity of the bone marrow and pancytopenia. The pathogenesis is thought to be multifactorial $(1,2)$. In acquired AA, immunologic suppression of hematopoiesis seems to be one pathogenetic mechanism (3) which may be mediated either by a disorder of cellular immunity or by the secretion of hematopoiesis-inhibiting soluble factors. An intrinsic defect of the hematopoietic stem cell has been suggested by studies with long-term bone marrow cultures $(4,5)$. Also, successful hematopoietic reconstitution after bone marrow transplantation (6) seems to imply that a stem cell defect plays a central role in the pathogenesis of AA. However, the comparatively high incidence of graft failure in patients with AA (6) seems to indicate that in addition a defect of the hematopoietic microenvironment may be of relevance. Abnormalities of the hematopoietic microenvironment in patients with AA have previously been described and might involve disturbance of stromal cell to stem cell contact (7) as well as altered secretion of growth factors (8-13).

Received September 15, 1994; accepted June 14, 1995.

Correspondence: Dagmar Dilloo, M.D., Division of Bone Marrow Transplantation, St. Jude Children's Research Hospital, 332 North Lauderdale, P.O. Box 318, Memphis TN 38101-0318.
Among the growth factors produced by stromal cells are GM-CSF and IL-6 (14-16). GM-CSF stimulates proliferation and differentiation of myeloid progenitors $(17,18)$. IL-6 induces megakaryopoiesis (19), and in synergy with other cytokines enhances multilineage colony formation (20). As a pluripotent cytokine, IL- 6 also functions as a mediator of the acute phase response (21) and host defense mechanisms. Release of GM-CSF and IL-6 from stromal cells is enhanced by IL-1 (22, 23 ) and TNF- $\alpha$ (24). Several viruses have also been shown to induce IL-6 production in infected host cells (25). In vitro infection of bone marrow stromal cells with CMV leads to perturbation of stromal cell function $(26,27)$ and has been postulated as a mechanism of marrow suppression in immunocompromised patients. In this study, we investigated the production of GM-CSF and IL-6 in bone marrow fibroblasts from three children with acquired $\mathrm{AA}$ and two children with Fanconi anemia in response to stimulation with IL-1, TNF- $\alpha$, and viral challenge with CMV.

\section{METHODS}

Patients. Five children aged 4-15 y with AA were studied, three with acquired AA and two with Fanconi anemia. All 
patients with acquired AA had suffered from longstanding disease (24-60 mo). Two of them were classified as patients with severe $\mathrm{AA}$, and they had received red cell and platelet transfusions. At the time of bone marrow sampling one patient was treated with androgens and one with cortisone. The patients with Fanconi anemia suffered from nonsevere AA of short duration (1-12 mo).

Stromal cell cultures. Bone marrow specimens from patients and healthy individuals donating for bone marrow transplantation were obtained from the posterior iliac crest. After informed consent, a small aliquot was used for the following investigations. Bone marrow MNC were isolated by FicollHypaque density gradient centrifugation. Erythrocytes contaminating the MNC fraction were lysed in ammonium chloride on ice for $5 \mathrm{~min}$. Subsequently MNC were washed twice with PBS and suspended at a concentration of $2 \times 10^{9}$ cells/ $\mathrm{L}$ in $\alpha$-modified Eagle's medium (Sigma Chemical Co., Deisenhofen, FRG) supplemented with $10 \%$ (vol/vol) heat-inactivated FCS (GIBCO, Eggenstein, FRG) and $1.7 \times 10^{-6} \mathrm{M}$ methylprednisolone. MNC $\left(4 \times 10^{5}\right)$ were plated in 12 -well culture plates (Costar, Cambridge, MA). Cell cultures were maintained at $37^{\circ} \mathrm{C}, 5 \% \mathrm{CO}_{2}$, and $98 \%$ humidity. Nonadherent cells were removed by weekly complete renewal of culture medium. After growth of the adherent cell fraction to near confluence, cells were treated with $0.5 \mathrm{~g} / \mathrm{L}$ trypsin/ $0.53 \mathrm{mM}$ EDTA $4 \mathrm{Na}$ and transferred to new culture plates. After four to five passages, stromal cell cultures consisted predominately of fibroblasts with $10-15 \%$ endothelial cells and less than $2 \%$ myeloid cells as assessed by flow cytometry. For stimulation of cytokine production, bone marrow fibroblasts of the fourth to fifth passage were incubated with 30000 IU of IL-1- $\alpha / \mathrm{L}$ (Genzyme, Cambridge, MA) or 50000 IU of TNF- $\alpha / \mathrm{L}$ (Sigma Chemical Co., Deisenhofen, Germany).

Infection of bone marrow fibroblasts with $C M V$. Bone marrow fibroblasts were infected with 1:1 mixture of the CMV laboratory strains AD 169 and Davies II. Fibroblasts were incubated with virus-containing supernatant at a tissue culture infection dosis $50\left(\mathrm{TCID}_{50}\right)$ of $10^{-5}$ for $1 \mathrm{~h}$ and washed. Fibroblasts were then stimulated with cytokines as described above with each experimental condition being set up in duplicates. Fibroblasts were either stimulated immediately after infection to assess IL- 6 production during the early phase of $\mathrm{CMV}$ infection or at $10 \mathrm{~d}$ after initial infection for assessment of IL-6 production during prolonged CMV infection. At $3 \mathrm{~d}$ postinfection, no CPE could be observed in either bone marrow fibroblasts from patients with AA nor from NC. Ten days after CMV infection, the frequency of CPE per well was $34 \pm 4 \%$ in bone marrow fibroblasts from patients with AA and $30 \pm$ $7 \%$ in NC. Trypan blue stains of CMV-infected fibroblast layers from patients with $\mathrm{AA}$ and $\mathrm{NC}$ demonstrated that loss in cell viability generally corresponded to the frequency of CPE.

Cytokines. Three days after stimulation of bone marrow fibroblasts, GM-CSF and IL-6 concentrations in the supernatant were assessed by ELISA using the GM-CSF "Insight GM" test kit (Medical Resources Limited, Brookvale, Australia) and the "Quantikine" IL-6 kit (Research \& Diagnostic Systems, Minneapolis, MN).
RNA purification. Four hours after stimulation of bone marrow fibroblasts with cytokines, total cellular RNA was isolated by phenol extraction in the presence of vanadyl ribonucleoside complex and precipitated with absolute ethanol. The recovery was $1-2 \mu \mathrm{g} / 10^{6}$ cells as assessed by spectral photometry. Samples $(10 \mu \mathrm{g})$ of isolated RNA were separated by agarose-formaldehyde gel electrophoresis. Concentration and integrity were verified by staining of ribosomal bands with ethidium bromide. Next, alkaline transfer $(0.05 \mathrm{M} \mathrm{NaOH})$ to Hybond $\mathrm{N}$ nylon membranes (Amersham Buchler, Braunschweig, FRG) was performed. Before hybridization the position of ethidium bromide-stained $28 \mathrm{~S}$ and $18 \mathrm{~S}$ rRNA was marked on the filter for subsequent calibration of cytokine mRNA signals. IL-6 mRNA measures $1.3 \mathrm{~kb}$.

Northern blot. An IL-6-specific antisense mRNA probe was generated in a two-step procedure. Initially a polymerase chain reaction with human genomic DNA was performed using a T7 promotor-coupled 3' (GGA ATA CGA CTC ACT ATA GGA AGA TGG ACT GCA GGA ACT CCTT) and 5' (AAC TCC TCC TCC ACA AGC) oligonucleotide. The $3^{\prime}$ oligonucleotide and the $5^{\prime}$ oligonucleotide used in the polymerase chain reaction stem from the exon $1 / 2$ and exon 5 of the IL- 6 gene (30), respectively. Subsequently, the IL-6 specific antisense mRNA probe is generated in the presence of $\left[{ }^{32} \mathrm{P}\right]$ UTP (DuPont NEN, Dreieich, FRG) in a T7-polymerase assay (Boehringer Mannheim, FRG). Filters were prehybridized for $3 \mathrm{~h}$ at $58^{\circ} \mathrm{C}$ in $50 \%$ ( vol/vol) formamide, $2.5 \mathrm{mM}$ phosphate buffer $(\mathrm{pH} 6.5), 5 \times$ SSC ( $0.75 \mathrm{M} \mathrm{NaCl}, 75 \mathrm{mM}$ sodium citrate), $5 \times$ Denhard's solution ( $1 \mathrm{~g} / \mathrm{L}$ Ficoll, $1 \mathrm{~g} / \mathrm{L}$ polyvinylpyrrolidone, $1 \mathrm{~g} / \mathrm{L}$ BSA), $1 \mathrm{~g} / \mathrm{L}$ SDS, $60 \mathrm{mg} / \mathrm{L}$ salmon sperm DNA, $200 \mathrm{mg} / \mathrm{L}$ yeast RNA, and $10 \%$ (vol/vol) dextran sulfate. In addition, the hybridization buffer contained the labeled antisense mRNA. The filters were incubated for $20 \mathrm{~h}$ at $58^{\circ} \mathrm{C}$. They were then washed in a multistep fashion with $2 \mathrm{~g} / \mathrm{L} \mathrm{SDS} / 2 \times \mathrm{SSC}(0.3 \mathrm{M}$ $\mathrm{NaCl}, 30 \mathrm{mM}$ sodium citrate) at $58^{\circ} \mathrm{C}$ for $30 \mathrm{~min}$, then $1 \mathrm{~g} / \mathrm{L}$ $\mathrm{SDS} / 0.2 \times \mathrm{SSC}(30 \mathrm{mM} \mathrm{NaCl}, 3 \mathrm{mM}$ sodium citrate $)$ at $60^{\circ} \mathrm{C}$ and at $68^{\circ} \mathrm{C}$ for $60 \mathrm{~min}$ each. Subsequently the filters were incubated in $2 \times \mathrm{SSC}$ containing $5 \mathrm{mg} / \mathrm{L}$ RNase A for $3 \mathrm{~min}$ at $37^{\circ} \mathrm{C}$ for further reduction of nonspecific binding. After a final wash with $2 \times \mathrm{SSC}$ for $3 \mathrm{~min}$ at $37^{\circ} \mathrm{C}$, filters were exposed to $3 \mathrm{M} \mathrm{x}$-ray film with intensification screen at $-70^{\circ} \mathrm{C}$.

Statistical analysis. Patients' data were compared with data from five healthy age-matched bone marrow donors serving as NC. For descriptive statistics mean values and standard errors were calculated. The Mann Whitney $U$ test was performed to detect differences between groups; the paired $t$ test was used to evaluate differences within the NC. $p$ values of 0.05 or less were considered significant.

\section{RESULTS}

Bone marrow stromal cell cultures, consisting predominately of fibroblasts, were established from three children with acquired AA, two children with Fanconi anemia, and five NC. Baseline GM-CSF production in bone marrow fibroblasts from patients with AA (44 $\pm 5 \mathrm{ng} / \mathrm{L}$; mean $\pm \mathrm{SE})$ did not differ significantly from GM-CSF production in NC (91 $\pm 40 \mathrm{ng} / \mathrm{L})$, neither did stimulated GM-CSF production in patients with AA 


\section{A: GM-CSF Production in Stromal Cells}

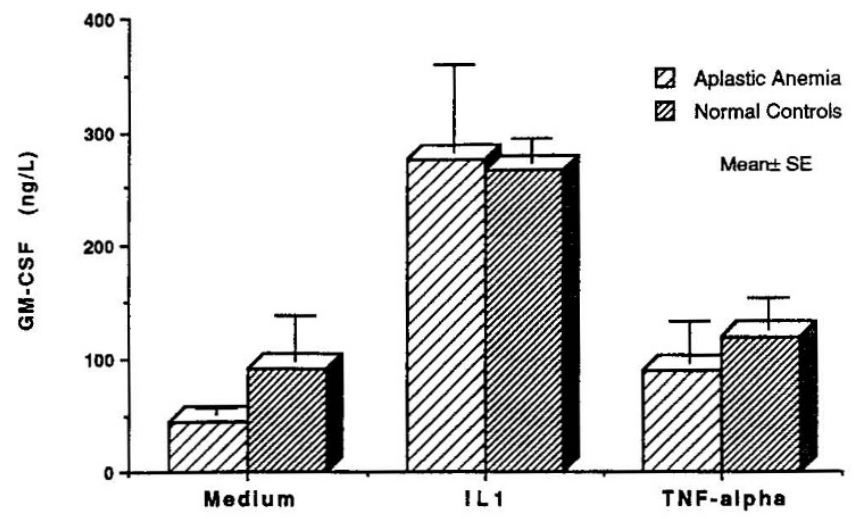

B: IL6 Production in Stromal cells

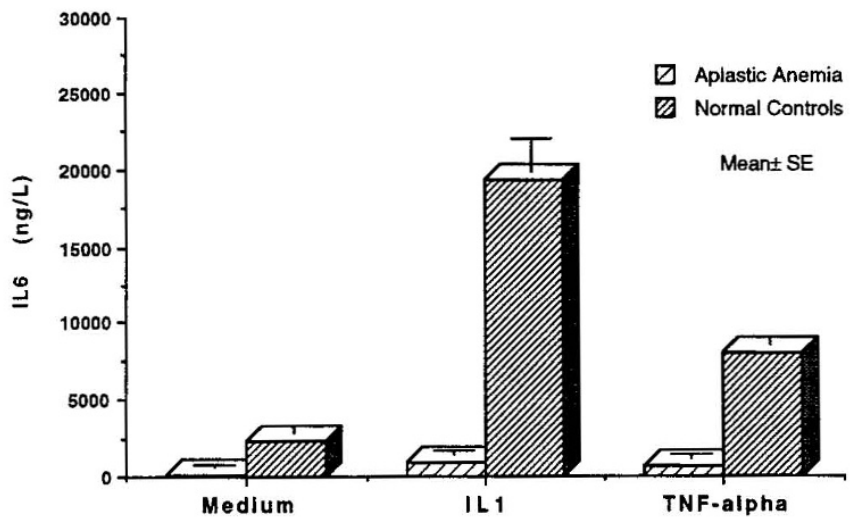

Figure 1. GM-CSF $(A)$ and IL-6 $(B)$ protein production in bone marrow fibroblasts from patients with AA and NC after culture for $3 \mathrm{~d}$ in the absence (medium) and presence of stimulation with $30000 \mathrm{IU} / \mathrm{L} \mathrm{IL}-1$ or $50000 \mathrm{IU} / \mathrm{L}$ TNF- $\alpha$.

(IL-1: $277 \pm 77 \mathrm{ng} / \mathrm{L}$; or TNF- $\alpha: 89 \pm 37 \mathrm{ng} / \mathrm{L}$ ) when compared with NC (IL-1: $266 \pm 38 \mathrm{ng} / \mathrm{L}$; TNF- $\alpha$ : $119 \pm 27$ $\mathrm{ng} / \mathrm{L})$ (Fig. 1A). In contrast, baseline IL-6 production in bone marrow fibroblasts from patients with AA $(184 \pm 49 \mathrm{ng} / \mathrm{L})$ is significantly reduced in comparison to NC $(2349 \pm 459 \mathrm{ng} / \mathrm{L}$, $p=0.003$ ) (Fig. $1 B$ ). Also, after stimulation with IL-1 (935 \pm $257 \mathrm{ng} / \mathrm{L})$ or TNF- $\alpha(678 \pm 203 \mathrm{ng} / \mathrm{L}) \mathrm{IL}-6$ production in bone marrow fibroblasts from patients with AA is significantly lower than in NC under the respective stimulatory conditions (IL-1: $19354 \pm 2115 \mathrm{ng} / \mathrm{L}, p=0.002$; TNF- $\alpha: 7970 \pm 475 \mathrm{ng} / \mathrm{L}, p$ $=0.003)$. IL- 6 measurements from each patient with AA studied are specified in Table 1.

Several viruses have been shown to modulate host cell IL-6 production. We investigated baseline and cytokine-induced IL-6 production in CMV-infected bone marrow fibroblasts from patients with acquired $\mathrm{AA}$ and NC. Effects of CMV infection on cytokine production could not be studied in fibroblasts from patients with Fanconi anemia, as cellular destruction was pronounced shortly after CMV infection due to the pathognomonic cellular fragility.

Three days after infection with the CMV laboratory strains AD 169 and Davies II, IL-6 concentrations in stromal cell
Table 1. IL-6 protein production ( $\mathrm{ng} / \mathrm{L})$ in bone marrow fibroblasts from three children with acquired aplastic anemia $(a A A)$ and two children with Fanconi anemia (FA) after culture for $3 d$ in the absence (medium) and presence of stimulation with $30000 \mathrm{IU} / \mathrm{L}$ $I L-1$ or 50000 IU/L TNF- $\alpha$

\begin{tabular}{lccc}
\hline Patients & Medium & IL- 1 & TNF- $\alpha$ \\
\hline aAA & 375 & 1700 & 300 \\
aAA & 116 & 1103 & 1348 \\
aAA & 172 & 1150 & 925 \\
FA & 145 & 330 & 590 \\
FA & 110 & 390 & 275 \\
\hline
\end{tabular}

supernatants were assessed (Fig. 2). CMV-infected bone marrow fibroblasts from patients with AA exhibit some increase in baseline (975 $\pm 169 \mathrm{ng} / \mathrm{L})$ and cytokine-induced IL-6 production (IL-1: $5332 \pm 1934 \mathrm{ng} / \mathrm{L}$; TNF- $\alpha: 3522 \pm 1324 \mathrm{ng} / \mathrm{L}$ ) when compared with uninfected bone marrow fibroblasts (baseline: $221 \pm 79 \mathrm{ng} / \mathrm{L} ;$ IL-1: $1318 \pm 192 \mathrm{ng} / \mathrm{L}$; TNF- $\alpha$ : 858 $\pm 304 \mathrm{ng} / \mathrm{L}$ ). However, stimulation of IL-6 production in response to viral challenge is significantly lower in bone marrow fibroblasts from patients with AA than in CMVinfected bone marrow fibroblasts from NC (baseline: $2114 \pm$ $156 \mathrm{ng} / \mathrm{L}, p=0.02$; IL-1: $29958 \pm 2635 \mathrm{ng} / \mathrm{L}, p=0.01$; TNF- $\alpha: 11802 \pm 1708 \mathrm{ng} / \mathrm{L}, p=0.03)$.
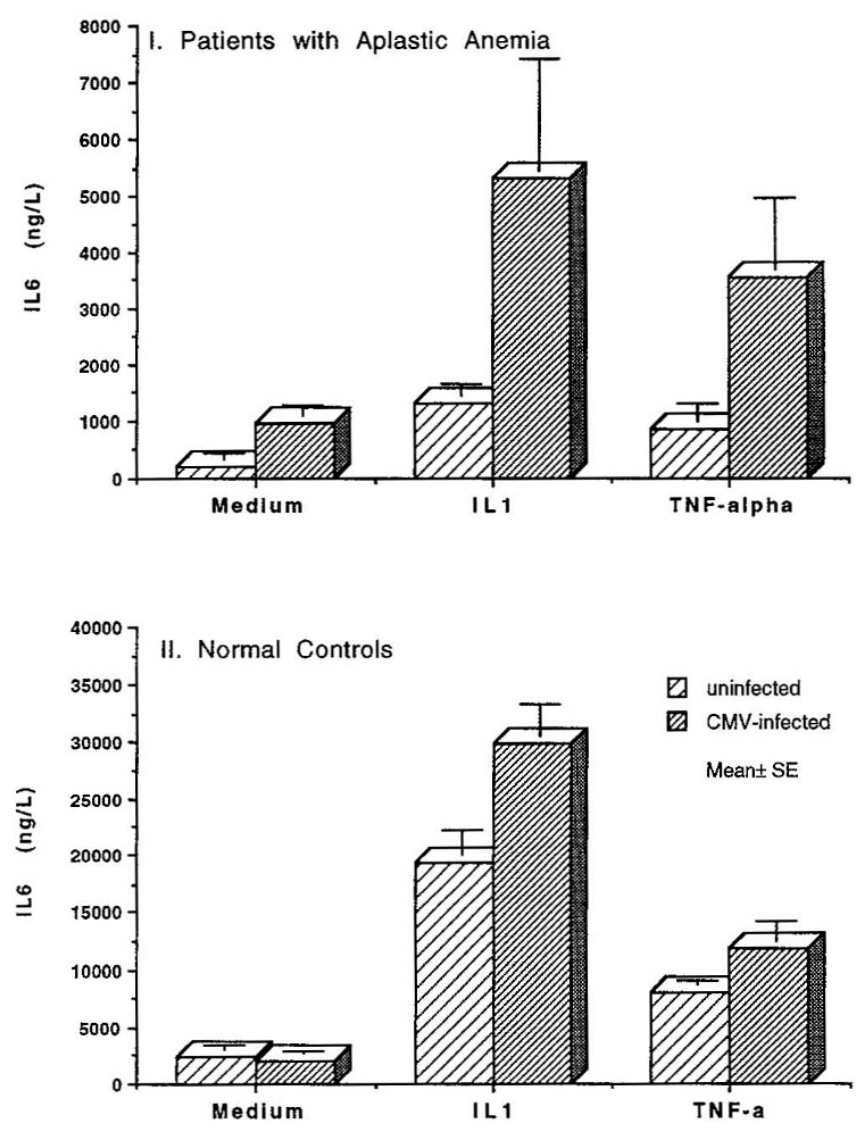

Figure 2. IL-6 protein production in bone marrow fibroblasts from patients with AA $(I)$ and $\mathrm{NC}(I I) 3 \mathrm{~d}$ after infection with a mixture of CMV laboratory strains ADA169 and Davies II and subsequent culture in the absence (medium) or presence of stimulation with $30000 \mathrm{IU} / \mathrm{L}$ IL-1 or $50000 \mathrm{IU} / \mathrm{L} \mathrm{TNF}-\alpha$. Please note the change of scale in the $y$ axis between patients with AA and NC. 
Ten days after CMV-infection, stromal cell cultures were restimulated with cytokines. After additional $3 \mathrm{~d}$ of culture, IL-6 concentrations in stromal cell supernatants were assessed (Fig. 3). In patients with AA, cytokine-induced IL-6 production in CMV-infected bone marrow fibroblasts (IL-1: $93 \pm 49$ $\mathrm{ng} / \mathrm{L}$; TNF- $\alpha: 71 \pm 14 \mathrm{ng} / \mathrm{L}$ ) was markedly lower than in uninfected cell cultures (IL-1: $923 \pm 441 \mathrm{ng} / \mathrm{L}$; TNF- $\alpha$ : 2074 $\pm 514 \mathrm{ng} / \mathrm{L})$. In contrast in $\mathrm{NC}$, baseline $(4114 \pm 1054 \mathrm{ng} / \mathrm{L})$ and TNF- $\alpha$-induced $(9116 \pm 1026 \mathrm{ng} / \mathrm{l})$ IL-6 production remained elevated in CMV-infected bone marrow fibroblasts when compared with their uninfected controls (baseline: 1588 $\pm 434 \mathrm{ng} / \mathrm{L}, p=0.02 ;$ TNF- $\alpha: 6556 \pm 803 \mathrm{ng} / \mathrm{L}, p=0.007)$. In $\mathrm{NC}, \mathrm{CMV}$-mediated inhibition of IL-6 production was observed only upon stimulation with IL-1 (CMV-infected: $14059 \pm 2671 \mathrm{ng} / \mathrm{L}$; uninfected: $21773 \pm 5340 \mathrm{ng} / \mathrm{L}, p=$ 0.04 ). Yet, inhibition was only $35 \%$ in comparison to $90 \%$ in patients with AA. As described in Methods, there was no difference in CMV-induced CPE between bone marrow fibroblasts from patients with acquired AA and NC. Inhibition of IL-6 production during prolonged CMV infection was further demonstrated by Northern blot analysis (Fig. 4). Ten days after CMV infection, bone marrow fibroblasts from patients with AA and NC were stimulated with IL-1. After $4 \mathrm{~h}$, mRNA was extracted for analysis. The ethidium bromide-stained rRNA bands document RNA integrity. In patients with AA, the IL-6
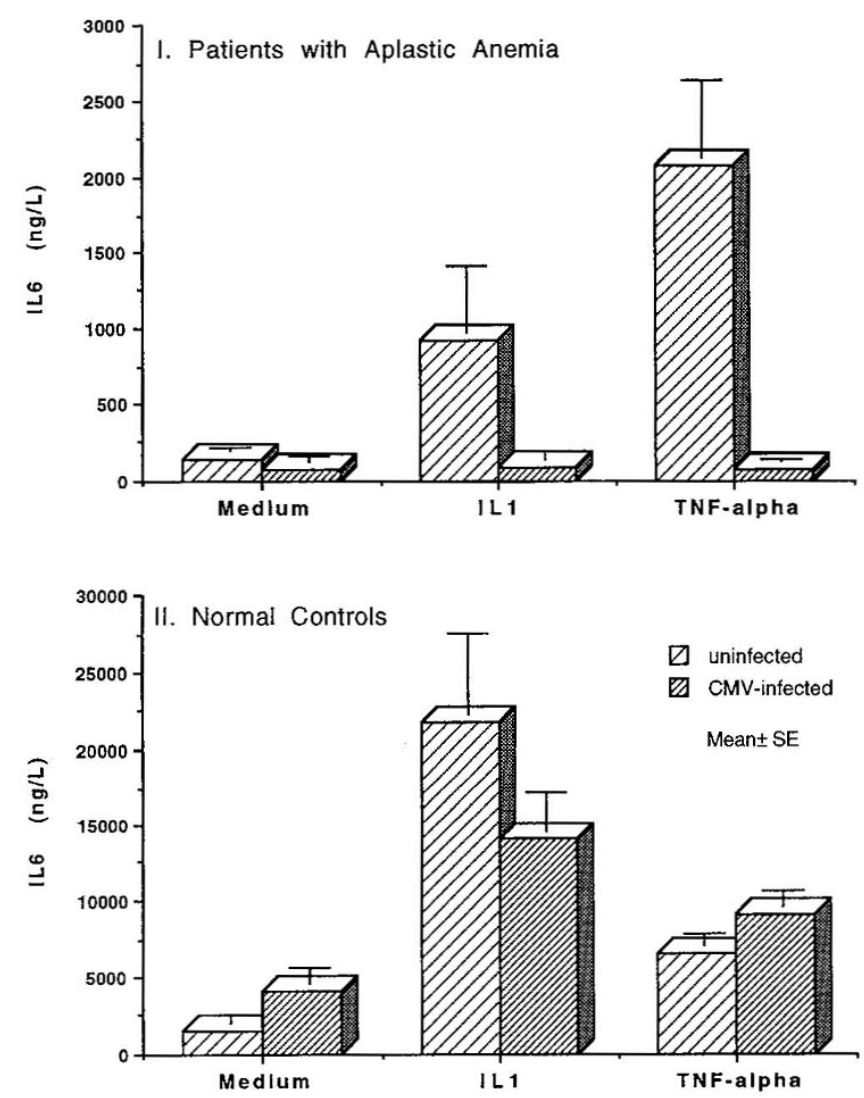

Figure 3. IL-6 protein production in bone marrow fibroblasts from patients with $\mathrm{AA}(I)$ and $\mathrm{NC}(I I) 10 \mathrm{~d}$ after infection with $\mathrm{CMV}$ and subsequent culture for $3 \mathrm{~d}$ in the absence (medium) or presence of stimulation with $30000 \mathrm{IU} / \mathrm{L}$ IL-1 or $50000 \mathrm{IU} / \mathrm{L}$ TNF- $\alpha$. Please note the change of scale in the $y$ axis between patients with $\mathrm{AA}$ and $\mathrm{NC}$.

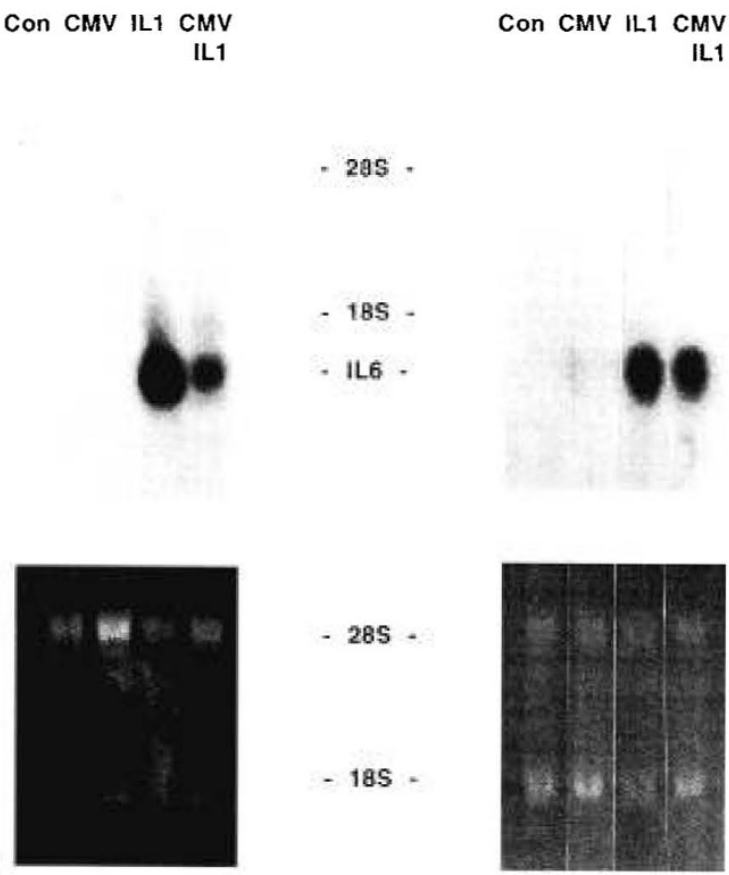

patient with aplastic anemia

Figure 4. IL-6 mRNA production in bone marrow fibroblasts from patients with aplastic anemia and normal controls ten days after infection with CMV and subsequent culture for four hours in the absence or presence of stimulation with 30000 IU/L IL-1. Uninfected fibroblasts cultured in medium alone (Con) or in the presence of IL- 1 were also assessed for IL-6 mRNA production. Accumulation of IL- 6 mRNA was assessed by Northern blot analysis. The IL- 6 specific mRNA signal (upper panel) is indicated. Ethidium bromide stain of ribosomal $18 \mathrm{~S}$ and $28 \mathrm{~S}$ RNA bands (lower panel) indicate the total amount of RNA loaded.

mRNA specific signal is markedly reduced in CMV-infected bone marrow fibroblasts when compared with uninfected fibroblasts. In bone marrow fibroblasts from $\mathrm{NC}$, CMVmediated reduction of IL-6-specific mRNA accumulation is less pronounced than in patients with AA.

\section{DISCUSSION}

AA is a disease of diverse etiologies $(1,2)$. Defects of the bone marrow microenvironment have been suggested as one possible pathogenetic mechanism (8-13). Yet, its actual contribution to hematopoietic insufficiency in man is still controversial. Bone marrow stromal cells exert their regulatory effects on hematopoiesis in part by the production of cytokines. We investigated constitutive and induced production of GMCSF and IL- 6 by adherent bone marrow stromal cells from patients with AA. Cytokine production was assessed after several passages of bone marrow stromal cells yielding an adherent cell layer of predominately fibroblasts deficient of myeloid cells. In our experimental system, there was no difference in both baseline and induced GM-CSF production between bone marrow fibroblasts from patients with AA or NC. In contrast, constitutive IL-6 production in bone marrow 
fibroblasts from patients with AA was less than 10\% of IL-6 production in NC. IL-6 production in these patients was also severely impaired upon stimulation of stromal cell cultures with either IL- 1 or TNF- $\alpha$ with less than $22 \%$ of IL- 6 production seen in NC. There was no difference in the IL-6 production defect between patients with acquired AA and Fanconi anemia.

A specific IL-6 production defect has previously been demonstrated for patients with Fanconi anemia in skin fibroblastoid cell lines $(28,29)$, whereas for patients with acquired AA, IL-6 production in stromal cells grown under long-term bone marrow culture conditions has been shown to be largely comparable to $\mathrm{NC}(30,31)$. However, in these studies, cytokine production in patients with acquired AA did show considerable variation. Variation in cytokine production among patients with acquired AA may in part be due to different patient characteristics. The three patients with acquired AA in our study had all suffered from longstanding disease, two of them from severe AA. Also, differences in the experimental systems used may account for the variation in stromal cell function observed in patients with AA. Thus, in cross-over studies using a long-term bone marrow culture system, bone marrow stromal cells from patients with acquired AA were shown to give sufficient support to normal progenitor growth $(4,5,7)$, whereas supernatants produced soley by bone marrow fibroblasts were found to exhibit defective colony-stimulating activity $(8-10)$. Our data provide evidence for a specific IL-6 production defect in bone marrow fibroblasts of some patients with AA in the presence of normal GM-CSF production. IL-6 is critical in inducing megakaryopoiesis (19) and potentiating IL-3-mediated stimulation of stem cell proliferation (20). Impaired production of IL-1 in patients with AA (32) in combination with an IL-6 production defect in bone marrow fibroblasts might lead to a deficient proliferative response of progenitor cells of particular relevance in high demand situations such as acute infections.

Increased IL-6 production in stromal as well as T cells represents an early antiviral defense mechanism (25). We examined the IL-6 response to viral challenge with CMV in bone marrow fibroblasts from patients with acquired $\mathrm{AA}$ and NC. During the early phase of infection, CMV stimulates constitutive as well as induced IL-6 protein production. However, bone marrow fibroblasts from patients with AA produce significantly less IL-6 protein in response to viral challenge than bone marrow fibroblasts from NC. During the late phase of CMV infection, cytokine-mediated IL-6 protein production was reduced by $90 \%$ in bone marrow fibroblasts from patients with AA, whereas in NC CMV-mediated inhibition of IL-6 production was $35 \%$ and could be demonstrated in IL-1stimulated fibroblasts only. As there was no difference in CMV-induced CPE between bone marrow fibroblasts from patients with acquired AA and NC, reduced IL-6 production in the three patients studied seems to be constitutive. In addition, reduction of IL-6 production during the later stage of CMVinfection was demonstrated on the mRNA level. Again inhibition of IL-6 mRNA accumulation was more profound in IL-1-stimulated bone marrow fibroblasts from patients with AA than from NC.
We demonstrated that, in some patients with acquired AA, IL-6 production in bone marrow fibroblasts is not only reduced constitutively and in response to stimulation with cytokines, such as IL-1 or TNF- $\alpha$, but also in response to viral challenge. This indicates that a functionally abnormal microenvironment does play a role in some cases of AA. Viral infections of bone marrow fibroblasts in association with inhibition of IL-6 production might potentiate hematopoietic suppression in these patients.

Acknowledgments. The authors thank Dr. Adams for critical discussion of our data and the donation of the CMV laboratory strains ADA 169 and Davies II. We also acknowledge Barbara Buttlies and Sandra Schaefer for their expert technical assistance.

\section{REFERENCES}

1. Frickhofen N, Liu JM, Young NS 1990 Etiologic mechanisms of hematopoietic failure. Am J Pediatr Hematol Oncol 12:385-395

2. Young NS 1993 The pathogenesis and Pathophysiology of Aplastic Anemia In: Hoffmann R, Benz EJ, Shattie SJ, Furie B, Cohen HF (eds) Hematology, Basic Principles and Practice, Churchill-Livingston, New York, pp 122-159

3. Torok-Storb B 1990 Etiological mechanisms in immune-mediated aplastic anemia. Am J Pediatr Hematol Oncol 12:396-401

4. Marsh JCW, Chang J, Testa NG, Hows JM, Dexter TM 1990 The hematopoietic defect in aplastic anemia assessed by long-term marrow culture. Blood 76:1748-1757

5. Marsh JCW, Chang J, Testa NG, Hows JM, Dexter TM 1991 In vitro assessment of marrow "stem cell" and stromal cell function in aplastic anemia. Br J Haematol 78:258-267

6. Gluckman E, Horowitz MM, Champlin RE, Hows JM, Bacigulapo A, Biggs JC Camitta BM, Gale RP, Gordon-Smith EC, Marmont AM, Masaoka T, Ramsay NKC, Rimm AA, Rozman C, Sobocinski KA, Speck B, Bortin MM 1992 Bone marrow transplantation for severe aplastic anemia: influence of conditioning and graft versus host disease prophylaxis regimens on outcome. Blood 79:269-275

7. Novitzky N, Jacobs P 1991 Marrow stem cell and stroma cell function in aplastic anemia. Br J Haematol 79:531-533

8. Gordon MY, Gordon-Smith EC 1983 Bone marrow fibroblast function in relation to granulopoiesis in aplastic anemia. Br J Haematol 53:483-489

9. Juneja HS, Gardner FH, Minguell JJ, Helmer III RE 1984 Abnormal marrow fibroblasts in aplastic anemia. Exp Hematol 12:221-230

10. Juneja HS, Gardner FH 1985 Functionally abnormal marrow stromal cells in aplastic anemia. Exp Hematol 13:194-199

11. Hotta T, Kato T, Maeda H, Yamao H, Yamada H, Saito H 1985 Functional changes in marrow stromal cells in aplastic anemia. Acta Haematol 74:65-69

12. Hirata J, Umemura T, Kaneko S, Nishimura J, Motomura S, Ibayashi H 1987 Difference of bone marrow adipocyte colony-forming capacity between aplastic anemia and iron deficiency anemia. Leuk Res 12:179-183

13. Migliaccio AR, Migliaccio G, Adamson JW, Torok-Storb B 1992 Production of granulocyte colony-stimulating factor and granulocyte-macrophage-colonystimulating factor after interleukin-1 stimulation of marrow stromal cell cultures from normal or aplastic anemia donors. J Cell Physiol 152:199-206

14. Quesenberry P, Temeles D, McGrath H, Lowry P, Meyer D, Kittler ELW, Deacon D, Kister K, Crittenden R, Srikumar K 1991 Long-term marrow cultures: human and murine systems. J Cell Biochem 45:273-278

15. Kittler ELW, McGrath H, Temeles D, Crittenden R, Kister K, Quesenberry P 1992 Biologic significance of constitutive and subliminal growth factor production by bone marrow stroma. Blood 79:3168-3178

16. Neumainitis J, Andrews DF, Mochizuki DY, Lilly MB, Singer JW 1989 Human marrow stromal cells: response to interleukin-6 (IL-6) and control of IL-6 expression. Blood 74:1929-1935

17. Sieff CA, Emerson SG, Donahue RE Nathan DG 1985 Human recombinant granulocyte macrophage colony-stimulating factor: a multilineage hematopoietin. Science 230:1171-1173

18. Metcalf D, Begley CG, Johnson GR, Nicola NA, Vadas MA Lopez AF, Williamson DJ, Wong GG, Clark SC, Wang EA 1986 Biologic properties in vitro of a recombinant human granulocyte macrophage colony-stimulating factor. Blood 67:37-45

19. Warren MK, Conroy LB, Rose JS 1989 The role of interleukin 6 and interleukin 1 in megakaryocyte development. Exp Hematol 17:1095-1099

20. Leary AG, Ikebuchi KS, Hirai Y, Wong GG, Ogawa M 1988 Synergism between Interleukin-6 and Interleukin-3 in supporting proliferation of human hematopoietic stem cells: comparison with interleukin- $1 \alpha$. Blood 71:1759-1763

21. Oldenburg HSA, Rogy MA, Lazarus DD, Van Zee KJ, Keeler BP, Chizzonite RA, Lowry SF, Moldawer BL 1993 Cachexia and the acute-phase response in inflammation are regulated by interleukin-6. Eur J Immunol 23:1889-1894

22. Yang YC, Tsai S, Wong GG, Clark SC 1988 Interleukin-1 regulation of hematopoietic growth factor production by human stromal fibroblasts. J Cell Physiol 134:292296 
23. Eaves CJ, Cashman JD, Kay RL, Dougherty GJ, Otsuka T, Gaboury LA, Hogge D, Lansdorp PM, Eaves AE, Humphries RK 1991 Mechanisms that regulate the cell cycle of very primitive hematopoietic cells in long-term human marow cultures. II. Analysis of positive and negative regulators produced by stromal cells within the adherent layer. Blood 78:110-117

24. Broudy VC, Kaushansky K, Segal GM, Harlan JM, Adamson JW 1986 Tumor necrosis factor type a stimulates human endothelial cells to produce granulocyte/macrophage colony-stimulating factor. Proc Natl Acad Sci USA 83:74677471

25. Seghal PB, Helfgott DC, Santham U, May LT 1988 Regulation of the acute phase and immune response in viral disease. Enhanced expression of the beta 2-interferon/ hepatocyte-stimulating factor/interleukin-6 gene in virus-infected human fibroblasts. J Exp Med 167:1951-1961

26. Apperley JF, Dowding C, Hibbin J, Buiter J, Matutes E, Sissons PJ, Gordon M, Goldman JM 1988 The effect of cytomegalovirus on hematopoiesis: in vitro evidence for selective infection of marrow stromal cells. Exp Hematol 17:38-45
27. Simmons P, Kaushansky K, Torok-Storb B 1990 Mechanism of cytomegalovirusmediated myelosuppression: perturbation of stromal cell function versus direct infection of myeloid cells. Proc Natl Acad Sci USA 87:1386-1390

28. Rosselli F, Sanceau J, Wietzerbin J, Moustacchi E 1992 Abnormal lymphokine production: a novel feature of the genetic disease Fanconi anemia. Hum Genet 89:42-48

29. Bagby Gc, Segal GM, Auerbach AD, Onega T, Kecble W, MC Heinrich 1993 Constitutive and induced expression of hematopoietic growth factor genes by fibroblasts from children with fanconi anemia. Exp Hematol 21:1419-1426

30. Kojima S, Matsuyama T, Kodera Y 1992 Hematopoietic growth factors released by stromal cells from patients with aplastic anemia. Blood 79:2256-2261

31. Hirayama Y, Kohgo Y, Matsunaga T, Ohi S, Sakamaki S, Niitsu Y 1993 Cytokine mRNA expression of bone marrow stromal cells from patients with aplastic anaemia and myelodysplastic syndrome. Br J Haematol 85:676-683

32. Gascón P, Scala G 1988 Decreased interleukin-1 production in aplastic anemia. Am J Med 85:668-674 